\title{
Marketed under Abbreviated New Drug Application
}

National Cancer Institute

\section{Source}

National Cancer Institute. Marketed under Abbreviated New Drug Application. NCI

Thesaurus. Code C73584.

A category specifying that a product is marketed under an Abbreviated New Drug Application. 